\title{
Comparing soil biogeochemical processes in novel and natural boreal forest ecosystems
}

\author{
S. A. Quideau ${ }^{1}$, M. J. B. Swallow ${ }^{1}$, C. E. Prescott ${ }^{2}$, S. J. Grayston ${ }^{2}$, and S.-W. Oh \\ ${ }^{1}$ Department of Renewable Resources, University of Alberta, 442 Earth Sciences Building, Edmonton, AB T6G 2E3, Canada \\ ${ }^{2}$ Department of Forest and Conservation Sciences, Faculty of Forestry, University of British Columbia, Vancouver, \\ BC V6T 1Z4, Canada \\ ${ }^{3}$ Department of Chemistry, Mokpo National University, Muan, Chonnam 534-729, Republic of Korea
}

Correspondence to: S. A. Quideau (sylvie.quideau@ualberta.ca)

Received: 27 December 2012 - Published in Biogeosciences Discuss.: 30 April 2013

Revised: 10 July 2013 - Accepted: 18 July 2013 - Published: 27 August 2013

\begin{abstract}
Emulating the variability that exists in the natural landscape prior to disturbance should be a goal of soil reconstruction and land reclamation efforts following resource extraction. Long-term ecosystem sustainability within reclaimed landscapes can only be achieved with the reestablishment of biogeochemical processes between reconstructed soils and plants. In this study, we assessed key soil biogeochemical attributes (nutrient availability, organic matter composition, and microbial communities) in reconstructed, novel, anthropogenic ecosystems, covering different reclamation treatments following open-cast mining for oil extraction. We compared the attributes to those present in a range of natural soils representative of mature boreal forest ecosystems in the same area of Northern Alberta. Soil nutrient availability was determined in situ with resin probes, organic matter composition was described with ${ }^{13} \mathrm{C}$ nuclear magnetic resonance spectroscopy and soil microbial community structure was characterized using phospholipid fatty acid analysis. Significant differences among natural ecosystems were apparent in nutrient availability and seemed more related to the dominant tree cover than to soil type. When analyzed together, all natural forests differed significantly from the novel ecosystems, in particular with respect to soil organic matter composition. However, there was some overlap between the reconstructed soils and some of the natural ecosystems in nutrient availability and microbial communities, but not in organic matter characteristics. Hence, our results illustrate the importance of considering the range of natural landscape variability and including several soil biogeochemical attributes when comparing novel, anthropogenic
\end{abstract}

ecosystems to the mature ecosystems that constitute ecological targets.

\section{Introduction}

Processes of soil formation do not vary randomly across natural landscapes. Instead, their spatial pattern is determined by the combined actions of defined soil-forming factors, elegantly coined in 1941 by Hans Jenny to include vegetation, climate, geology (parent material), topographic conditions, and time (Jenny, 1941). Two or more of these factors typically covary across the landscape, and their complex interactions yield local differences in soil characteristics and soil functioning. The concept of pedodiversity as a way to describe soil spatial diversity, including its link to biodiversity and landscape ecology, has more recently emerged as a key concept in soil science (McBratney, 1992; Ibánez and Bockheim, 2013). Similarly, linkages between the belowground (soil) and aboveground (vegetation) components are increasingly recognized as important determinants of terrestrial ecosystem processes (e.g., Wardle et al., 2004). From a more applied, land-management perspective, the implicit linkage between soils and their environment forms the basis of ecological classification schemes. For instance, in Northern Alberta, the ecosite classification system stratifies ecological components of natural forested landscapes based on broad vegetation and topographic properties, which in turn allows for the prediction of the soil nutrient and moisture 
regimes of these defined ecological units (Beckingham and Archibald, 1996).

Some effects of mining activities on terrestrial ecosystems may be long-lived and extend well past land reconstruction and revegetation (Bradshaw, 1997; Vetterlein and Hüttl, 1999). One of these potentially long-term impacts is the obliteration of causal relationships between the newly reconstructed soils and their environment. Hence, land reclamation needs to focus on rebuilding complete ecosystems that include feedback mechanisms and interactions among the various components (Bradshaw, 1984; Chapin et al., 1996). From this point of view, a better understanding of pedodiversity and aboveground-belowground linkages in reconstructed ecosystems can help achieve the goals of restoration ecology (McBratney, 1992; Kardol and Wardle, 2010). Whilst reconstructed soils are a central feature of these novel landscapes, surprisingly little is known about their characteristics compared to their natural counterparts.

Surface mining of the Alberta oil sands deposits located in Western Canada has to date disturbed over $700 \mathrm{~km}^{2}$ of boreal forest (Alberta Government, 2011). In these boreal ecosystems, the forest floor is a storehouse of nutrients and a major determinant of biogeochemical fluxes (Prescott et al., 2000a). Factors influencing forest floor quality include the overstory and understory vegetation growing on site, stand age, and mineral parent material (Lamarche et al., 2004). Boreal and tundra ecosystems have tightly regulated internal biogeochemical cycling between plants and soils (Bashkin, 2003), and their soil organic matter composition, microbial communities, and plant communities are interlinked (Ohtonen and Väre, 1998; Hannam et al., 2004, 2006; Eskelinen et al., 2009). This equilibrium between soil chemical and biochemical properties may be disrupted following disturbance (Chaer et al., 2009). Prior research in the Athabasca oil sands region demonstrated that organic matter composition, nutrient availability, and microbial communities in these reclaimed soils differed from mature upland forest soils (Turcotte et al., 2009; Rowland et al., 2009; Dimitriu et al., 2010). These past studies looked at each of these variables separately, and did not specifically examine the inherent variability present in the natural landscape.

The objective of this study was to determine how soil biogeochemical functioning of novel ecosystems reconstructed following oil sands mining compared to the boreal forests that constitute targets for restoration. We concurrently assessed several key soil attributes that we used as surrogates of ecosystem biogeochemical functioning, namely: soil nutrient availability, organic matter composition, and microbial communities. We examined how variable these attributes were in natural ecosystems, and investigated potential links amongst them. One of the ecological goals of soil reclamation is to emulate the variability that exists in the natural landscape prior to disturbance. Hence, we were interested in testing whether the soils that had developed on any of the reclaimed sites were similar in any of the relevant measurable attributes to natural soils across the natural range of variability that exists in this region.

\section{Materials and methods}

\subsection{Study sites}

Climate in the Athabasca oil sands region presents sharp seasonal contrasts. Winters are long and cold, with a mean monthly air temperature for January of $-19^{\circ} \mathrm{C}$ (Beckingham and Archibald, 1996). Summers are short but warm, with a mean monthly air temperature for July of $17^{\circ} \mathrm{C}$, an estimated frost-free period $\left(0^{\circ} \mathrm{C}\right)$ of 60 to 70 days, and a plant growing season averaging between 90 and 100 days (Crown and Twardy, 1970). Mean annual precipitation is $478 \mathrm{~mm}$ and falls predominantly as rain $(342 \mathrm{~mm})$ during the summer months. Till, fluvial and lacustrine plains were deposited in the Fort McMurray region from the advance and retreat of glacial ice and subsequent postglacial sorting following the last Wisconsin glaciation from 70000 to 10000 yr ago (Crown and Twardy, 1970). These surficial deposits constitute the geological parent materials in which soils from the experimental area have developed. Organic soils are found in depressional and level landscape positions where surface waters accumulate, and generally contain the decomposed remains of sphagnum and feather mosses, Labrador tea and black spruce (Picea mariana (Mill.) BSP). Dystric brunisolic soils (Soil Classification Working Group, 1998) are well drained and have developed in acidic, coarsetextured, glaciofluvial and eolian materials. Gray Luvisols are well to moderately well drained and have developed from till and glaciolacustrine sediments (Crown and Twardy, 1970).

A total of 41 sites were chosen from the network of soil and vegetation long-term monitoring plots established in the Athabasca oil sands region in 2000 (OSVRC, 1998). All sites are located within an $86 \mathrm{~km}$ radius around Ft. McMurray, Alberta, Canada $\left(56^{\circ} 43^{\prime} \mathrm{N} 111^{\circ} 21^{\prime} \mathrm{W}\right)$. Fifteen undisturbed sites were selected to span the range of natural variability of forested ecosystems within the region (Table 1). According to the Northern Alberta ecosite classification system (Beckingham and Archibald, 1996), sites increase in nutrient and water content from ecosite a1 to ecosite d3 (Table 1). Ecosites a and $b$ may be water-deficient for periods of the year, occur on brunisolic soils and exhibit either a canopy dominated by jack pine (Pinus banksiana (Lamb.)) for the a1 ecosites or stands mixed with aspen (Populus tremuloides (Michx.)) and conifers (ecosites b1 and b3). Ecosites d occur on luvisolic soils and are defined by their mesic moisture regime and medium nutrient regime (Beckingham and Archibald, 1996). Changes in canopy composition along a natural successional trajectory entail a shift from pure aspen stands (d1) to mixed stands of aspen and white spruce 
(Picea glauca (Moench) Voss) for the d2 ecosites and finally to stands of pure white spruce (d3).

Land reclamation practices following open-cast mining involve placement of several layers of various soil materials, geological deposits, and products of the mining activity in order to reconstruct soils. For this study, a total of 26 sites was selected to capture the five main reclamation practices that have been used in the oil sands region (Table 1). Overburden (OB), which is the geological substrate ( $>3 \mathrm{~m}$ depth) removed to access the mineable oil sands, may encompass lean oil sands $(<10 \%$ oil $)$ as well as Cretaceous and Pleistocene deposits. Tailings sand (TS), the residue remaining once bitumen extraction is complete, is primarily composed of a medium to fine sand (>90\% sand). Salvaged mineral soils and surficial geological deposits $(<3 \mathrm{~m}$ depth) are referred to as "secondary" materials $\left(2^{\circ}\right)$. Organic amendments applied to cover these mineral substrates are referred to as "peat mineral mixes" (PM) as they consist of a mixture of peat materials and their underlying mineral substrates salvaged from low land areas. Finally, the reclamation practice of "direct placement" (DP) refers to the use of surficial peat and mineral materials $(<1 \mathrm{~m})$ salvaged from adjacent areas and placed directly on the reclaimed sites, i.e., with no stockpiling. Following soil reconstruction, sites are typically sown with barley (Hordeum vulgare L.) during the first year to control erosion and are subsequently planted to nursery-grown white spruce, aspen, and jack pine.

\subsection{Field sampling and laboratory analysis}

At each of the 41 study sites (15 natural and 26 reclaimed), one composite representative sample was obtained in July 2005 by randomly collecting ten mineral soil samples $(0-$ $10 \mathrm{~cm}$ ) within $1-2 \mathrm{~m}$ from the perimeter edge of $10 \mathrm{~m}$ by $40 \mathrm{~m}$ plots that had been previously established (OSVRC, 1998). All samples were transported in an icebox to the laboratory and sieved $(<4 \mathrm{~mm})$ to exclude the fresh litter materials corresponding to the L horizon (Soil Classification Working Group, 1998). Samples destined for organic matter characterization were oven-dried at $60^{\circ} \mathrm{C}$, while samples for microbial characterization were kept frozen at $-86^{\circ} \mathrm{C}$ until they were freeze-dried in preparation for analysis.

In situ nutrient bioavailability was estimated by incubating plant root simulator ( $\mathrm{PRS}^{T M}$ ) probes (Western Ag Innovations, Inc., Saskatoon, SK, Canada), which include resin membranes to capture nutrient anions and cations from the soil solution. Four pairs of cation and anion probes were incubated randomly at 5 to $10 \mathrm{~cm}$ depth within each site. Following incubation, the probes were washed with deionized water and returned to Western Ag Innovations, Inc. for elution with $0.5 \mathrm{M} \mathrm{HCl}$ and nutrient concentration analysis, including colorimetric ammonium $\left(\mathrm{NH}_{4}^{+}\right)$, nitrate $\left(\mathrm{NO}_{3}^{-}\right)$and phosphate $\left(\mathrm{PO}_{4}^{3-}\right)$ analysis on a segmented flow Autoanalyzer III (Bran and Luebbe, Inc., Buffalo, NY, USA), and P, $\mathrm{K}, \mathrm{S}, \mathrm{Ca}, \mathrm{Mg}, \mathrm{Al}, \mathrm{Fe}, \mathrm{Mn}, \mathrm{Cu}, \mathrm{Zn}, \mathrm{B}$, and $\mathrm{Pb}$ analysis by In- ductively Coupled Plasma (ICP) spectroscopy (PerkinElmer Optima 3000-DV, PerkinElmer, Inc., Shelton, CT, USA). The probe data reported here $\left(\mathrm{mmol}\right.$ per $10 \mathrm{~cm}^{-2}$ of resin area per day) correspond to a total burial period of 95 days (Rowland et al., 2009).

For the characterization of soil microbial communities using phospholipid fatty acid (PLFA) analysis, polar lipids were extracted from freeze-dried samples using a modified Bligh and Dyer protocol (Hannam et al., 2007; Dimitriu et al., 2010). Extracts were purified on pre-packed silicic acid columns (Agilent Technologies, Wilmington, DE, USA) to separate polar lipids from neutral lipids and glycolipids, and subsequently subjected to mild alkaline methanolysis. The resulting fatty-acid methyl esters were separated using an Agilent 6890 Series capillary gas chromatograph (Agilent Technologies, Wilmington, DE, USA) equipped with a $25 \mathrm{~m}$ Ultra 2 (5\% phenyl)-methylpolysiloxane column using hydrogen as the carrier gas. Individual peaks were identified and quantified (nmol g${ }^{-1}$ ) using the MIDI peak identification software (MIDI, Inc., Newark, DE, USA). The standardized $X: Y \omega Z$ nomenclature for fatty acids was used to identify PLFAs, where $X$ is the number of carbon atoms, $Y$ is the number of double bonds, and $Z$ is the position of the first double bond from the aliphatic end $(\omega)$ of the molecule. Prefixes " $\mathrm{i}$ " and "a" indicate branching at the second and third carbon atom, respectively, from the $\omega$ end, the suffix "c" corresponds to a c transfiguration, and $2 \mathrm{OH}$ or $3 \mathrm{OH}$ indicates a hydroxyl group at the second or third carbon from the carboxyl end of the molecule, respectively.

Samples for organic matter characterization were isolated using a combination of density separation $\left(\mathrm{d}<1 \mathrm{~g} \mathrm{~cm}^{-3}\right)$ and sieving to yield $>53 \mu \mathrm{m}$ low-density materials, which represent the carbon pool most responsive to environmental changes (Turcotte et al., 2009). The chemical composition of these materials was analyzed using ramped crosspolarization (RAMP-CP) ${ }^{13} \mathrm{C}$ Nuclear Magnetic Resonance (NMR) spectroscopy on a Bruker Avance $400\left(B_{0}=9.4 T\right.$, $\left.v_{\mathrm{L}}\left({ }^{13} \mathrm{C}\right)=100.6 \mathrm{MHz}\right)$ spectrometer, using a $13 \mathrm{kHz}$ spinning frequency, a $1 \mathrm{H} 90^{\prime \prime}$ pulse width of $4.0 \mathrm{~ms}$, a $1 \mathrm{~ms}$ contact time and a $5 \mathrm{~s}$ pulse delay. Four to eight thousand scans were acquired for each sample. The ${ }^{13} \mathrm{C}$ chemical shifts were referenced relative to Tetramethylsilane (TMS) $\left(\delta_{\text {iso }}=\right.$ $0.0 \mathrm{ppm}$ ), and the Bruker's WIN-NMR package was used to estimate the relative integrated areas (\% of total spectral area) of the following five regions between 0 and $192 \mathrm{ppm}$ : 0 $45 \mathrm{ppm}$ region, attributed to alkyl carbons; $45-112 \mathrm{ppm}$, attributed to O-alkyl carbons; $112-140 \mathrm{ppm}$, attributed to aromatic carbons; $140-165 \mathrm{ppm}$, attributed to phenolic carbons; and 140-192 ppm, attributed to carbonyl carbons.

\subsection{Statistical analysis}

Due to the multivariate nature of the dataset, we used non-metric multi-dimensional scaling (NMS) ordinations to identify potential patterns in the soil bioavailable nutrients, 
Table 1. Site characteristics.

\begin{tabular}{|c|c|c|c|c|c|}
\hline $\begin{array}{l}\text { Ecosite or } \\
\text { reclamation } \\
\text { treatment }\end{array}$ & Site & $\begin{array}{l}\text { Location } \\
\left({ }^{\circ} \mathrm{N},{ }^{\circ} \mathrm{W}\right)\end{array}$ & Soil & Vegetation & $\begin{array}{l}\text { Age } \\
(\mathrm{yr})\end{array}$ \\
\hline a1 & 10 & $57.0735,-111.5944$ & Dystric Brunisol & pine & 48 \\
\hline a1 & 27 & $57.5051,-111.4370$ & Dystric Brunisol & pine & 82 \\
\hline b1 & 29 & $57.1020,-111.6402$ & Dystric Brunisol & aspen and pine & 48 \\
\hline b1 & 62 & $57.5012,-111.5208$ & Dystric Brunisol & aspen and pine & 67 \\
\hline b1 & 63 & $57.4980,-111.5229$ & Dystric Brunisol & aspen and pine & 63 \\
\hline b3 & 2 & $57.0053,-111.4517$ & Dystric Brunisol & white spruce and aspen & 101 \\
\hline b3 & 49 & $57.1030,-111.6367$ & Dystric Brunisol & white spruce and aspen & 52 \\
\hline d1 & 4 & $56.9534,-111.7230$ & Gray Luvisol & aspen & 75 \\
\hline d1 & 8 & $57.2604,-111.4775$ & Gray Luvisol & aspen & 57 \\
\hline d1 & 61 & $56.4390,-111.1902$ & Gray Luvisol & aspen & 58 \\
\hline $\mathrm{d} 2$ & 19 & $56.4139,-111.1942$ & Gray Luvisol & white spruce and aspen & 73 \\
\hline $\mathrm{d} 2$ & 50 & $56.6448,-111.0946$ & Gray Luvisol & white spruce and aspen & 79 \\
\hline $\mathrm{d} 2$ & 57 & $56.3924,-111.4405$ & Gray Luvisol & white spruce and aspen & 75 \\
\hline d3 & 20 & $57.3234,-111.2254$ & Gray Luvisol & white spruce & 163 \\
\hline d3 & 21 & $57.2852,-111.2743$ & Gray Luvisol & white spruce & 87 \\
\hline A & 36 & $57.0648,-111.6618$ & $\mathrm{PM} / 2^{\circ} / \mathrm{TS}$ & white spruce & 6 \\
\hline A & 37 & $57.1005,-111.6455$ & $\mathrm{PM} / 2^{\circ} / \mathrm{TS}$ & white spruce & 20 \\
\hline A & 40 & $57.0591,-111.6682$ & $\mathrm{PM} / 2^{\circ} / \mathrm{TS}$ & white spruce and aspen & 11 \\
\hline A & 87 & $57.0844,-111.6094$ & $\mathrm{PM} / 2^{\circ} / \mathrm{TS}$ & white spruce and aspen & 3 \\
\hline A & 88 & $57.0915,-111.6299$ & $\mathrm{PM} / 2^{\circ} / \mathrm{TS}$ & white spruce and aspen & 12 \\
\hline A & 89 & $57.0906,-111.6794$ & $\mathrm{PM} / 2^{\circ} / \mathrm{TS}$ & white spruce and aspen & 1 \\
\hline B & 3 & $57.0663,-111.6637$ & DP/TS & pine & 8 \\
\hline B & 38 & $57.0470,-111.6563$ & DP/TS & aspen and pine & 14 \\
\hline B & 39 & $57.1021,-111.6610$ & DP/TS & white spruce and aspen & 4 \\
\hline B & 42 & $57.0748,-111.6665$ & DP/TS & aspen and pine & 5 \\
\hline B & 46 & $56.9991,-111.7318$ & DP/TS & white spruce and aspen & 6 \\
\hline E & 7 & $56.9968,-111.5913$ & $\mathrm{PM} / 2^{\circ} / \mathrm{OB}$ & white spruce & 7 \\
\hline E & 14 & $57.0009,-111.5744$ & $\mathrm{PM} / 2^{\circ} / \mathrm{OB}$ & aspen & 6 \\
\hline $\mathrm{E}$ & 43 & $56.9909,-111.5638$ & $\mathrm{PM} / 2^{\circ} / \mathrm{OB}$ & white spruce and aspen & 18 \\
\hline E & 86 & $56.9988,-111.6151$ & $\mathrm{PM} / 2^{\circ} / \mathrm{OB}$ & aspen & 1 \\
\hline $\mathrm{H}$ & 1 & $56.9776,-111.4640$ & $\mathrm{PM} / \mathrm{TS}$ & pine & 9 \\
\hline $\mathrm{H}$ & 16 & $56.9872,-111.5300$ & $\mathrm{PM} / \mathrm{TS}$ & white spruce and pine & 5 \\
\hline $\mathrm{H}$ & 17 & $56.9819,-111.5015$ & $\mathrm{PM} / \mathrm{TS}$ & pine & 9 \\
\hline $\mathrm{H}$ & 24 & $56.9986,-111.4608$ & $\mathrm{PM} / \mathrm{TS}$ & white spruce & 30 \\
\hline $\mathrm{H}$ & 30 & $56.9817,-111.5179$ & $\mathrm{PM} / \mathrm{TS}$ & pine & 29 \\
\hline I & 25 & $57.0236,-111.4998$ & $\mathrm{PM} / \mathrm{OB}$ & white spruce and pine & 17 \\
\hline I & 28 & $56.9909,-111.5373$ & $\mathrm{PM} / \mathrm{OB}$ & white spruce & 30 \\
\hline I & 32 & $56.9987,-111.5482$ & $\mathrm{PM} / \mathrm{OB}$ & white spruce and aspen & 18 \\
\hline I & 34 & $56.9881,-111.5406$ & $\mathrm{PM} / \mathrm{OB}$ & white spruce & 21 \\
\hline I & 75 & $56.9120,-111.4192$ & $\mathrm{PM} / \mathrm{OB}$ & white spruce and aspen & 1 \\
\hline
\end{tabular}

PM: mixture of peat and mineral substrate; $2^{\circ}$ : secondary (subsoil) material; TS: tailing sands; DP: direct placement; $\mathrm{OB}$ : overburden.

organic matter composition, and microbial community composition among natural sites and reclamation treatments. This ordination technique presents the advantage of not requiring normal distribution, nor does it assume linear relationships among variables (McCune and Grace, 2002). NMS organizes complex datasets in a reduced dimensional space (typically two dimensions) as to reveal similarities or dissimilarities in the original dataset structure. An optimal NMS solution results from the iterative search for the best repre- sentation within the reduced space. The strength of the NMS solution is expressed by the stress value, which indicates differences between the original data structure and the NMS solution. Generally, a NMS solution with a stress value $<10$ is determined to be reliable. All analyses were conducted using PCORD software (Version 5, MjM Software Design, Gleneden Beach, OR, USA). In terms of nutrient bioavailability, a total of 14 ions was used in the ordination, while five spectral NMR areas were included for organic matter 
characterization. Analysis of the microbial communities used all PLFAs with $<20$ carbons, which corresponded to a total of 80 PLFAs. Prior to the NMS analysis, all PLFAs were proportionalized on a mol $\%$ basis and were arcsine square-root transformed.

Data groupings were tested for significant differences in the NMS analysis using a multi-response permutation procedure (MRPP). Analyses were completed using the Sorensen distance, and Bonferroni corrections were used to control the family error rate for among-grouping comparisons. In addition to the probability value $p$, the MRPP test generates a $T$ value, which indicates separation among groups, with a larger $T$ reflecting a stronger separation, and an $A$ value, which is an index of within-group homogeneity compared to random expectation, with a larger $A$ indicating greater homogeneity (McCune and Grace, 2002). In addition, indicator species analyses were performed using the data groupings shown to be different by MRPP. This statistical method generates an indicator value based on the abundance and frequency of a particular variable (individual nutrient, NMR spectral area, or PLFA) in a given data grouping. A larger indicator value represents a stronger relationship between the variable and the given data grouping. The statistical significance of the indicator value was tested against a randomized Monte Carlo test.

\section{Results}

\subsection{Biogeochemical attributes in natural boreal forest soils}

For the natural forest soils (Fig. 1), three distinct ecosite groups were discriminated (Fig. 1). All ordinations attained a very low stress $(<10$ in all cases) after $40-70$ iterations. Solutions for the nutrients and organic matter variables were two-dimensional and the two axes explained $>95 \%$ of the data variance. Analysis of the microbial communities led to a three-dimensional solution, where the two axes presented in Fig. 1 accounted for $78 \%$ of the variance. Analysis of the PRS-probe data (nutrients) showed a clear separation of three significantly different groups: Group 1 , which included the a1 and b1 ecosites; Group 2, corresponding to the d1 ecosites; and Group 3, which included the b3, d2, and $\mathrm{d} 3$ ecosites. Preliminary analyses had indicated that the individual ecosite types contained in either Group 1 or Group 3 were not significantly different from one another.

Separation of these three groups was weaker but still significant for the PLFA data (microbial communities) as evidenced by their larger $p$ value than the nutrients (Table 2). Similarly, the $T$ value obtained from the MRPP analysis, which is an index of the separation among groups, and the A value, which indicates within-group homogeneity, were smaller for the microbial communities $(-4.5$ and 0.15 , respectively) than for the nutrients $(-7.3$ and 0.51$)$. The indi-
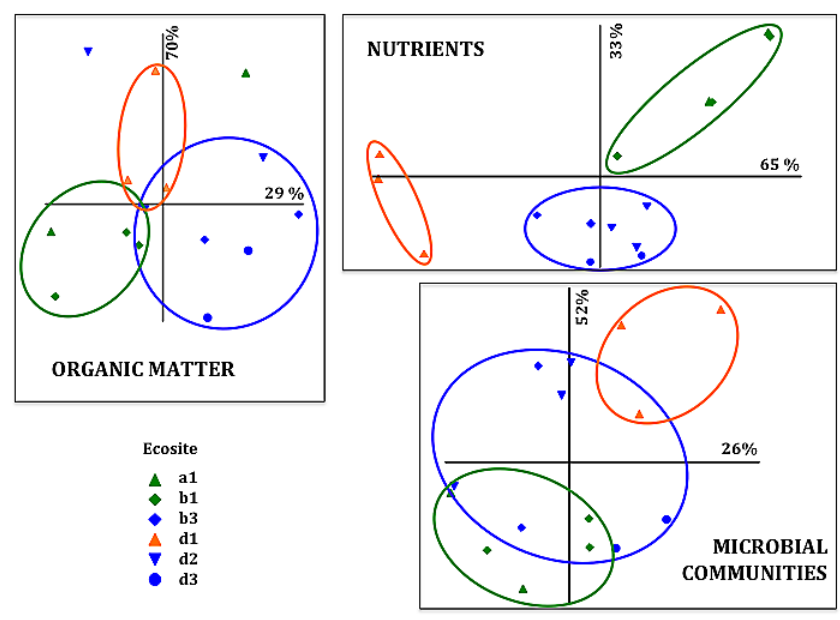

Fig. 1. NMS ordination biplots for soil nutrient supply (PRS), organic matter composition (NMR), and microbial community structure (PLFA) for the natural sites. Each point on the ordination corresponds to one site. Description of soil type and dominant vegetation for each ecosite are given in Table 1.

vidual Groups 1, 2, and 3, which, for the PRS data (nutrients), formed three distinct clusters clearly separated on the NMS graph (Fig. 1), yielded fairly large $T$ values $(\geq 4)$ in all pairwise comparisons (Table 2). The $T$ values were smaller and the $p$ values larger for the PLFA dataset, particularly comparing Groups 1 and 3. This weaker pair-wise separation is also noticeable in Fig. 1, where there is some overlap among cluster points for the different groups derived from the PLFA ordination. For organic matter composition $\left({ }^{13} \mathrm{C} N M R\right)$, separation among the three groups was much weaker than for either the nutrients or microbial communities, as illustrated by their larger $p$ value (0.07) and smaller $T$ and $A$ values (Table 2).

The differences among the natural sites in nutrients and microbial communities were linked to their respective tree covers (pine, aspen, and/or spruce) rather than to the associated soil types. Indeed, the b1 and b3 ecosites, which both occurred on brunisolic soils, belonged to two different groups, while Group 3 encompassed both Brunisols and Luvisols (Table 1). Group 1 was characterized by a cover of pine trees, either in pure stands (a1 ecosites) or in mixed stands (b1 ecosites); Group 2 corresponded to pure aspen stands (d1 ecosites), and Group 3 was characterized by the presence of white spruce, either in pure stands ( $\mathrm{d} 3$ ecosites) or in mixed stands (b3 and d2 ecosites).

Cations $(\mathrm{Ca}, \mathrm{Mg}, \mathrm{K}$, and $\mathrm{Na}$ ) were the only nutrients that were found to be significantly different among the three ecosite groupings (i.e., having a $p$ value $\leq 0.05$ and an indicator value $>30$ ) in the indicator species analysis (Table 3). The d1 ecosites, which support pure aspen stands, were different from the other two groups in that they had greater available $\mathrm{Ca}$ and $\mathrm{Mg}$. The indicator species analysis 


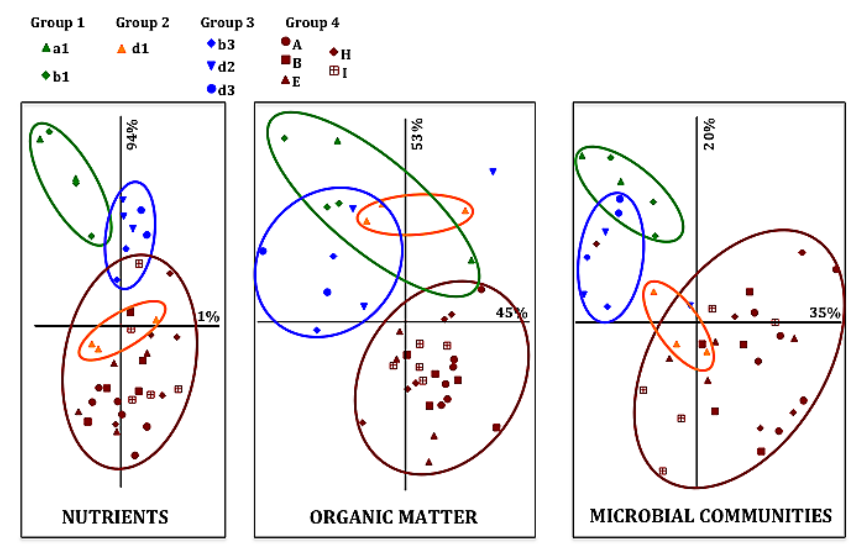

Fig. 2. NMS ordination biplots for soil nutrient supply (PRS), organic matter composition (NMR), and microbial community structure (PLFA) for the natural and the novel ecosystems. Each point on the ordination corresponds to one site. Descriptions of soil type and dominant vegetation for each ecosite and reclamation treatment are given in Table 1.

also detected seven significant PLFAs, with six of the seven indicative of the $\mathrm{d} 1$ ecosites. No significant indicators of ecosite types were found in the NMR data.

\subsection{Comparison of novel and natural ecosystem attributes}

The novel ecosystems failed to show any differentiation among the different reclamation treatments (Fig. 2). As opposed to the natural ecosites, which separated according to tree cover, the novel ecosystems also failed to show any separation by vegetation (Table 2). As illustrated by higher $p$ values $(0.25-0.53)$, separation by vegetation was even weaker than by reclamation treatment, with associated $p$ values ranging from 0.09 to 0.15 for the three biogeochemical criteria (soil nutrients, organic matter, and microbial communities). There was no correlative relationship between the age of the novel ecosystems (Table 1) and the biogeochemical variables (data not shown).

As the novel ecosystems did not differ from one another, we compare them as a group (i.e., Group 4) to the three distinct natural ecosite groups (Fig. 2). Separation between the natural and novel sites was most marked for the NMR data, as seen from the largest $T$ and $A$ values and the smallest $p$ value (Table 2). In all cases, the separation of natural and novel sites was very strong, and a low stress $(<9)$ was obtained after 48-70 iterations for all attributes. As was the case for the natural sites only (Fig. 1), solutions for the nutrients and organic matter variables as presented in Fig. 2 were twodimensional and $>95 \%$ of the data variance was explained by the two axes. In the case of the microbial communities, the solution was three-dimensional and the two axes presented in Fig. 2 accounted for $55 \%$ of the data variance.
The novel ecosystems (Group 4) strongly differed from all natural site groups in organic matter composition, as demonstrated by extremely small $p$ values for all pair-wise comparisons with Group 4 (Table 2). The pattern for both the microbial communities and nutrients was different in that Group 2 (d1 ecosites) was much closer to the reclaimed sites than either Group 1 or Group 3. In the case of the nutrients, Group 2 was enclosed within the larger point cluster composed of Group 4 sites (Fig. 2), and the corresponding $p$ value exceeded 0.05 (Table 2); the same relationship, albeit weaker with a marginally significant $p$ value (0.02) between Groups 2 and 4, was observed for the microbial communities (Fig. 2 and Table 2). For both variables, the reconstructed soils were furthest away from Group 1 ( $\mathrm{a} 1$ and $\mathrm{b} 1$ ecosites).

Indicator species analysis identified a few additional nutrients and PLFAs that were representative of the novel ecosystems (Tables 3 and 4). The reconstructed soils were characterized by high sulphur and nitrate concentrations, and the

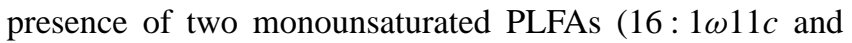
$i 17: 1 \omega 9 c$ ). In terms of the NMR results, the novel ecosystems were characterized by higher O-alkyl carbon than the natural sites ( $p$ value $\leq 0.05$ ), but no indicator value was $>30$.

\section{Discussion}

\subsection{Environmental controls on natural variability}

For the natural soils, vegetation cover was the main factor influencing separation among the different ecological units. The influence of tree species on key biogeochemical processes has been previously documented in Western Canadian forests, including influences on nutrient availability (Prescott et al., 2000c; Prescott and Vesterdal, 2005; Jerabkova et al., 2006), microbial communities (Leckie et al., 2004; Grayston and Prescott, 2005; Hannam et al., 2006), and organic matter characteristics (Hannam et al., 2004). In our study, the importance of the coniferous component in mixed stands was obvious, as the presence of either spruce or pine trees determined how boreal forest soils grouped in terms of nutrient availability. The unique influence of white spruce on forest floor microbial communities has been previously reported in mixedwood forests in northwestern Alberta, which are comparable to the forests studied here (Hannam et al., 2006; Swallow et al., 2009).

The relative importance of biotic versus abiotic determinants of soil biogeochemical processes is difficult to tease apart. Biotic factors such as forest vegetation type can be closely linked to factors such as soil organic matter composition (Quideau et al., 2001; Merilä et al., 2010), microbial community composition (Prescott and Grayston, 2013) and nutrient availability (Binkley and Giardina, 1998). Other studies have shown that abiotic conditions including climate and geology can have a stronger effect than forest canopy 
Table 2. Multi-response permutation procedure results for soil nutrient supply (PRS), organic matter composition (NMR), and microbial community structure (PLFA).

\begin{tabular}{|c|c|c|c|c|c|c|c|c|c|}
\hline & \multicolumn{3}{|c|}{ Nutrients } & \multicolumn{3}{|c|}{ Organic matter } & \multicolumn{3}{|c|}{ Microbial communities } \\
\hline & $T$ & $A$ & $p$ & $T$ & $A$ & $p$ & $T$ & $A$ & $p$ \\
\hline \multicolumn{10}{|c|}{ Natural ecosites (NMS groups) } \\
\hline 1 vs. 2 vs. 3 & -7.3 & 0.51 & $2 \times 10^{-5}$ & -1.6 & 0.09 & 0.07 & -4.5 & 0.15 & $3 \times 10^{-4}$ \\
\hline 1 vs. 2 & -4.0 & 0.58 & $1 \times 10^{-3}$ & -0.6 & 0.06 & 0.23 & -3.3 & 0.20 & $9 \times 10^{-3}$ \\
\hline 1 vs. 3 & -5.7 & 0.36 & $5 \times 10^{-3}$ & -1.6 & 0.08 & 0.07 & -2.6 & 0.09 & 0.02 \\
\hline 2 vs. 3 & -5.1 & 0.42 & $2 \times 10^{-3}$ & -1.0 & 0.06 & 0.15 & -3.0 & 0.08 & $6 \times 10^{-3}$ \\
\hline \multicolumn{10}{|l|}{ Novel ecosystems } \\
\hline Among treatments & -1.2 & 0.05 & 0.13 & -1.4 & 0.06 & 0.09 & -1.0 & 0.03 & 0.15 \\
\hline Among vegetation types & -0.6 & 0.03 & 0.25 & -0.2 & 0.01 & 0.53 & -0.3 & $<0.01$ & 0.47 \\
\hline \multicolumn{10}{|l|}{ All ecosystems } \\
\hline $\begin{array}{l}\text { Novel (group 4) } \\
\text { vs. all natural }\end{array}$ & -17.6 & 0.25 & $2 \times 10^{-8}$ & -22.3 & 0.36 & $<10^{-8}$ & -15.8 & 0.12 & $<10^{-8}$ \\
\hline 1 vs. 4 & -14.8 & 0.38 & $2 \times 10^{-7}$ & -14.2 & 0.28 & $3 \times 10^{-7}$ & -1.8 & 0.14 & $3 \times 10^{-7}$ \\
\hline 2 vs. 4 & -1.8 & 0.04 & 0.06 & -10.0 & 0.19 & $7 \times 10^{-6}$ & -2.4 & 0.06 & 0.02 \\
\hline 3 vs. 4 & -13.8 & 0.32 & $8 \times 10^{-7}$ & -14.8 & 0.23 & $2 \times 10^{-8}$ & -3.7 & 0.25 & $6 \times 10^{-3}$ \\
\hline
\end{tabular}

Group 1: a1 and b1 ecosites; Group 2: d1 ecosites; Group 3: b3, d2, and d3 ecosites; and Group 4: all novel ecosystems.

$T$ : separation among groups; $A$ : homogeneity within groups; $p$ : probability value.

Table 3. Nutrient indicator species analysis associated with site groups. Each value represents the mean indicator with standard deviation in parentheses, and the highest indicator value is in bold. Only nutrients that were found to be significantly different among groups are presented. The left side of the table shows comparison among natural ecosites (Groups 1, 2, and 3), while the right side shows comparison among all groups.

\begin{tabular}{|c|c|c|c|c|c|c|c|c|c|c|c|}
\hline \multirow[b]{2}{*}{ Nutrient } & \multirow[b]{2}{*}{ Mean } & \multicolumn{3}{|c|}{ Indicator Value } & \multirow{2}{*}{$\begin{array}{r}\text { Monte Carlo } \\
\qquad p<0.05\end{array}$} & \multirow[b]{2}{*}{ Mean } & \multicolumn{4}{|c|}{ Indicator Value } & \multirow{2}{*}{$\begin{array}{r}\text { Monte Carlo } \\
p<0.05\end{array}$} \\
\hline & & 1 & 2 & 3 & & & 1 & 2 & 3 & 4 & \\
\hline $\mathrm{NO}_{3}$ & & & & & & $33.5(4.2)$ & 18 & 20 & 21 & 42 & 0.048 \\
\hline $\mathrm{Ca}$ & $39.9(3.6)$ & 17 & 50 & 33 & 0.009 & $28.2(1.5)$ & 14 & 31 & 21 & 34 & $<0.001$ \\
\hline $\mathrm{Mg}$ & $41.3(4.4)$ & 17 & 57 & 26 & $<0.001$ & $27.7(1.4)$ & 16 & 36 & 22 & 27 & $<0.001$ \\
\hline $\mathrm{K}^{\circ}$ & $42.0(4.7)$ & 19 & 22 & 59 & $<0.001$ & $31.0(3.0)$ & 21 & 24 & 40 & 15 & 0.010 \\
\hline$S$ & & & & & & $30.9(2.9)$ & 11 & 26 & 20 & 42 & 0.002 \\
\hline $\mathrm{Na}$ & $40.7(4.0)$ & 58 & 9 & 34 & $<0.001$ & $32.0(3.5)$ & 42 & 16 & 30 & 12 & 0.011 \\
\hline
\end{tabular}

Group 1: a1 and b1 ecosites; Group 2: d1 ecosites; Group 3: b3, d2, and d3 ecosites; and Group 4: all novel ecosystems.

composition on forest floor nutrient concentrations and soil humus type (Lamarche et al., 2004; Ponge et al., 2011). The issue of scale may explain these apparent discrepancies. On a regional scale, climate conditions were the controlling factor influencing soil microbial communities (Brockett et al., 2012) and humus forms (Ponge et al., 2011), while at landscape and local scales, differences in soil biogeochemical processes were more directly derived from differences in tree species (Hannam et al., 2004; Grayston and Prescott, 2005). In our study, base cations $(\mathrm{Ca}, \mathrm{Mg}, \mathrm{K})$ were the only nutrients identified as indicative of specific ecosite groupings (Table 3). Although cation availability in the long term is controlled by mineral weathering from the soil parent material, plant uptake and biocycling mechanisms can influence availability especially in the forest floor and upper mineral soil (Quideau et al., 1996). In our study, pure aspen stands were associated with higher $\mathrm{Ca}$ and $\mathrm{Mg}$ concentrations. This is consistent with other studies reporting higher base cation concentrations under broadleaved tree species including aspen (Prescott et al., 2004, Hobbie et al., 2006).

In the present study, differences among mature forest soils were quite clear for nutrient availability, and were partially mirrored by differences in microbial communities (Fig. 1 and Table 2). Belowground communities and soil biodiversity are often assumed to be directly correlated to aboveground biotic factors, including vegetation composition (Wardle et al., 2004; Wall et al., 2010). Further, the regulation of carbon sources in boreal forests by heterotrophic soil microorganisms is considered to be closely associated with organic matter quality (Merilä et al., 2010), with microbial activity 
Table 4. PLFA indicator species analysis associated with site groups. Each value represents the mean indicator with standard deviation in parentheses, and the highest indicator value is in bold. Only PLFAs that were found to be significantly different among groups are presented. The left side of the table shows comparison among natural ecosites (Groups 1, 2, and 3), while the right side shows comparison among all groups.

\begin{tabular}{|c|c|c|c|c|c|c|c|c|c|c|c|}
\hline \multirow[b]{2}{*}{ PLFA } & \multirow[b]{2}{*}{ Mean } & \multicolumn{3}{|c|}{ Indicator Value } & \multirow{2}{*}{$\begin{array}{r}\text { Monte Carlo } \\
p<0.05\end{array}$} & \multirow[b]{2}{*}{ Mean } & \multicolumn{4}{|c|}{ Indicator Value } & \multirow{2}{*}{$\begin{array}{r}\text { Monte Carlo } \\
p<0.05\end{array}$} \\
\hline & & 1 & 2 & 3 & & & 1 & 2 & 3 & 4 & \\
\hline$a 15: 0$ & $32.0(12.6)$ & 0 & 69 & 13 & 0.010 & $27.3(8.13)$ & 0 & 44 & 8 & 24 & 0.040 \\
\hline $15: 1 \omega 6 c$ & $27.2(13.7)$ & 0 & 87 & 2 & 0.004 & $19.9(10.5)$ & 0 & 76 & 2 & 2 & 0.002 \\
\hline $15: 1 \omega 8 c$ & $37.6(11.2)$ & 80 & 0 & 12 & $<0.001$ & $21.4(10.8)$ & 78 & 0 & 11 & 0 & $<0.001$ \\
\hline $16: 1 \omega 11 c$ & & & & & & $29.5(4.34)$ & 2 & 21 & 8 & 40 & 0.003 \\
\hline$i 15: 03 \mathrm{OH}$ & $32.0(12.4)$ & 0 & 70 & 13 & 0.005 & $24.6(9.77)$ & 0 & 52 & 9 & 9 & 0.020 \\
\hline$i 17: 1 \omega 9 c$ & & & & & & $21.9(10.7)$ & 0 & 0 & 0 & 44 & 0.030 \\
\hline $16: 02 \mathrm{OH}$ & $29.8(13.4)$ & 0 & 71 & 8 & 0.020 & $19.0(10.1)$ & 0 & 66 & 8 & 1 & 0.003 \\
\hline$i 17: 03 \mathrm{OH}$ & 27.3 (13.9) & 0 & 89 & 2 & 0.001 & $20.3(10.4)$ & 0 & 75 & 1 & 3 & $<0.001$ \\
\hline $19: 1 \omega 9(11) c$ & $27.2(13.8)$ & 0 & 86 & 2 & 0.003 & $21.1(10.7)$ & 0 & 68 & 2 & 5 & 0.003 \\
\hline
\end{tabular}

Group 1: a1 and b1 ecosites; Group 2: d1 ecosites; Group 3: b3, d2, and d3 ecosites; and Group 4: all novel ecosystems.

typically being limited by the availability of carbon rather than other nutrients (Ekblad and Nordgren, 2002). However, in our study, the patterns of organic matter composition were much weaker than patterns observed for nutrient availability and microbial communities. It may be that solid-state NMR, while providing an overall fingerprint of organic matter composition, is not a good proxy for carbon availability. It may also be that organic matter characteristics as probed by NMR are not as readily quantifiable as nutrient availability and PLFA data and so do not show strong relationships with other factors. In all cases, it was evident that soil nutrient availability and microbial communities were linked to aboveground vegetation. It seems that the soils underneath a pure aspen canopy (Group 2) were different from the rest in that high $\mathrm{Ca}$ and $\mathrm{Mg}$ concentrations and different microbial communities were associated with this Group (Tables 3 and 4). While none of the identified PLFAs were specific biomarkers of bacterial groups or fungi, three PLFAs were hydroxy fatty acids ( $i 15: 03 \mathrm{OH}, 16: 02 \mathrm{OH}$, and $i 17: 03 \mathrm{OH})$, which are common components of Gram-negative lipopolysaccharides (Ratledge and Wilkinson, 1988).

\subsection{Novel vs. natural ecosystems}

The novel ecosystems differed from the natural boreal forests in the three biogeochemical criteria measured, although there was overlap for some of these sites in terms of nutrient availability. Soil organic matter composition, while displaying a relatively weak separation among natural ecosites, differed the most between the novel and the natural ecosystems. As reported previously (Turcotte et al., 2009), the strong O-alkyl carbon signal for the novel ecosystems is likely linked to the unaltered peat material used as an organic amendment on the reconstructed soils. Microbial communities in the reconstructed soils also differed significantly from all natural ecosite groupings, albeit less so than did organic matter. Re- constructed soils were characterized by the presence of two unsaturated PLFAs, one of which $(16: 1 \omega 11)$ has been reported to increase in concentration following litter amendment (Esperschütz et al., 2011). Characterization of organic matter and microbial communities as well as the interrelationship between them have often been used as simple measurements of reclamation success (e.g., Insam and Dosch, 1988; Banning et al., 2008; Hahn and Quideau, 2013). The chemical and physical characteristics of soil organic matter have been proposed as sensitive indicators related to changing environmental conditions (Leifeld and Kögel-Knabner, 2005; Turcotte et al., 2009), while the re-establishment of soil microbial communities similar to undisturbed environments has been recognized as a crucial target in mine restoration (Mummey et al., 2002; Machulla et al., 2005; Harris, 2009).

Although the reconstructed soils examined do not fully resemble the natural forest soils, there is some evidence that they may, with time and soil development, come to better emulate natural soils. Based on plant community composition and soil nutrient availability, Rowland et al. (2009) concluded that some of the reclamation treatments appear to develop into functioning forest ecosystems similar to those that occur naturally in this area after about 25 years. Studies of chronosequences of reconstructed soils under similar tree canopies detected a measurable evolution of organic matter composition with time (Sorenson et al., 2011). However, temporal changes in the soil microbial communities of the same novel ecosystems have been harder to establish (Dimitriu et al., 2010; Hahn and Quideau, 2013), suggesting that, at least in this boreal environment, soil microbial response may be lagging behind changes in organic matter composition and nutrient availability.

Novel ecosystems were characterized by higher $\mathrm{N}$ and $S$ concentrations than the natural sites (Table 3). This is 
consistent with the higher nitrate concentrations previously reported for oil sands reconstructed soils compared to the natural forest soils (McMillan et al., 2007; Rowland et al., 2009) and is likely due to the close proximity of the novel ecosystems to industrial emissions and greater atmospheric $\mathrm{N}$ deposition (Bytnerowicz et al., 2010; Hemsley, 2012). In all cases, the novel ecosystems (Group 4) and the $\mathrm{d} 1$ ecosites (Group 2) significantly differed in organic matter but had comparable nutrient availability (Fig. 2 and Table 2). This implies a disconnection between organic matter composition and nutrient availability in these soils. Disruption of the equilibrium between soil organic matter and biological activity may provide an index to quantify the amplitude of soil degradation (Chaer et al., 2009). This elegant paradigm is worth pursuing in future studies of novel ecosystems.

\section{Implications for reconstructed boreal ecosystems}

Biogeochemical processes affecting soils occur at vastly different time scales (Duchaufour, 1960; Targulian and Krasilnikov, 2007). Effects of long-term pedogenesis on boreal forest soils may be more limited than in other forest biomes, as they are relatively young soils with low mean annual temperatures that limit the rate of biological and pedogenic processes. For instance, in most Canadian soils, the extent of mineral weathering and clay alteration is minimal (Komada, 1979), since the prevalent pedogenic processes occurring in boreal soils, i.e., podzolization and lessivage, typically require several millennia to result in diagnostic soil horizons (e.g., Parsons and Herriman, 1976; Barrett and Scaetzl, 1992). In boreal forest ecosystems, biogeochemical cycling between trees and soils is shallower than in other settings and may be more closely associated to the forest floor than to the underlying mineral soils (Prescott et al., 2000b; Bashkin, 2003). It is therefore important that efficient organic matter-associated processes are re-established in novel boreal ecosystems, perhaps even more so than in other more temperate forest biomes. Results from this study, which showed some divergence between nutrient availability, microbial communities, and organic matter composition, illustrate the importance of including several biogeochemical criteria when assessing novel boreal ecosystems.

According to the Society of Ecological Restoration (SER, 2004), a restored ecosystem should exhibit similar diversity and community structure as reference (target) sites (RuizJaen and Aide, 2005). This concept was originally developed with aboveground communities in mind but should be extended to include belowground communities (Harris, 2009; Wall et al., 2010). In our study, reconstructed soils differed from natural soils in all three measured biogeochemical attributes (nutrient availability, organic matter composition, and microbial communities) and so cannot be considered to be restored ecosystems (according to the SER criteria) at this stage of development. While there is evidence that the reclaimed soils will share many attributes of natural soils within a few decades, it is unlikely that they will fully emulate natural soil horizonation, which develops over thousands of years. As pointed out by Chadzon (2008), novel forests emerging on human-modified landscapes cannot be expected to match the composition and structure of the original forest cover. In a similar fashion, reconstructed soils cannot be expected to fully emulate natural soils. Reconstructed soils in this region may therefore represent a case of novel ecosystems with novel species and novel abiotic conditions as defined by Hobbs et al. (2009). It may be more effective and realistic to determine if the reconstructed soils are able to maintain comparable ecosystem services and overall functioning. Answering this question requires that we better understand the links between structure and function in these reconstructed, novel ecosystems.

Acknowledgements. Direct financial support was provided by the Natural Sciences and Engineering Research Council (NSERC) of Canada and the Canadian Oil Sands Network for Research and Development. We would like to acknowledge Isabelle Turcotte and Sara Rowland, who conducted the field work and the necessary soil sampling.

Edited by: I. Kögel-Knabner

\section{References}

Banning, N. C., Grant, C. D., Jones, D. L., and Murphy, D. V.: Recovery of soil organic matter, organic matter turnover, and nitrogen cycling in a post-mining forest rehabilitation chronosequence, Soil Biol. Biochem., 40, 2021-2031, 2008.

Barrett, L. R. and Schaetzl, R. J.: An examination of podzolization near Lake Michigan using chronofunctions, Can. J. Soil Sci., 72, 527-541, 1992.

Bashkin, V. N.: Modern Biogeochemistry. Kluwer Academic Press, Dordrecht, the Netherlands, 561 pp., 2003.

Beckingham, J. D. and Archibald, J. H.: Field guide to ecosites of northern Alberta, Special Report 5, UBC Press, Vancouver BC, Canada, 1996.

Binkley, D. and Giardina, C.: Why do tree species affect soils? The Warp and Woof of tree-soil interactions, Biogeochemistry, 42, 89-106, 1998.

Bradshaw, A. D.: Ecological principles and land reclamation practice, Landscape Plan., 11, 35-48, 1984.

Bradshaw, A. D.: Restoration of mined lands- using natural processes, Ecol. Engin., 8, 255-269, 1997.

Brockett, B. F. T., Prescott, C. E., and Grayston, S. J.: Soil moisture is the major factor influencing microbial community structure and enzyme activities across seven biogeoclimatic zones in western Canada, Soil Biol. Biochem., 44, 9-20, 2012.

Bytnerowicz, A., Fraczek, W., Schilling, S., and Alexander, D.: Spatial and temporal distribution of ambient nitric acid and ammonia in the Athabasca Oil Sands Region, Alberta, J. Limnol., 69, 1121, 2010 .

Chaer, G., Myrold, D., and Bottomley, P. J.: A soil quality index based on the equilibrium between soil organic matter and bio- 
chemical properties of undisturbed coniferous forest soils of the Pacific Northwest, Soil Biol. Biochem., 41, 822-830, 2009.

Chapin, F. S., Torn, M. S., and Tateno, M: Principles of ecosystem sustainability, Am. Nat., 148, 1016-1037, 1996.

Chazdon, R. L.: Beyond deforestation: restoring forests and ecosystem services on degraded lands, Science, 320, 1458-1460, 2008.

Crown, P. H. and Twardy, A. G.: Soils of the Fort McMurray region, Alberta, and their relation to agricultural and urban development, Contribution M70-2, Alberta Institute of Pedology, University of Alberta, 52 pp., 1970.

Dimitriu, P. A., Prescott, C. E., Quideau, S. A., and Grayston, S. J.: Impact of reclamation of surface-mined boreal forest soils on microbial community composition and function, Soil Biol. Biochem., 42, 2289-2297, 2010.

Duchaufour, P.: Précis de pédologie, Masson, Paris, France, 482 pp., 1960.

Ekblad, A. and Nordgren, A.: Is growth of soil microorganisms in boreal forests limited by carbon or nitrogen availability?, Plant Soil, 242, 115-122, 2002.

Eskelinen, A., Stark, S., and Männistö, M.: Links between community composition, soil organic matter quality and microbial communities in contrasting tundra habitats, Oecologia, 161, 113123, 2009.

Esperschütz, J., Pérez-de-Mora, A., Schreiner, K., Welzl, G., Buegger, F., Zeyer, J., Hagedorn, F., Munch, J. C., and Schloter, M.: Microbial food web dynamics along a soil chronosequence of a glacier forefield, Biogeosciences, 8, 3283-3294, doi:10.5194/bg8-3283-2011, 2011.

Frouz, J., Pizl, V., Cienciala, E., and Kalcik, J.: Carbon storage in post-mining forest soil, the role of tree biomass and soil bioturbation, Biogeochemistry, 94, 111-121, 2009.

Grayston, S. J. and Prescott, C. E.: Microbial communities in forest floors under four tree species in coastal British Columbia, Soil Biol. Biochem., 37, 1157-1167, 2005.

Hahn, A. and Quideau, S. A.: Long-term effects of organic amendments on the recovery of plant and soil microbial communities following disturbance in the Canadian boreal forest, Plant Soil, 363, 331-344, doi:10.1007/s11104-012-1306-4, 2013.

Hannam, K. D., Quideau, S. A., Oh, S.-W., Kishchuk, B. E., and Wasylishen, R. E.: Forest floor composition in aspen- and sprucedominated stands of the boreal mixedwood forest, Soil Sci. Soc. Am. J., 68, 1735-1743, 2004.

Hannam, K. D., Quideau, S. A., and Kishchuk, B. E.: Forest floor microbial communities in relation to stand composition and timber harvesting in northern Alberta, Soil Biol. Biochem., 38, 2565-2575, 2006.

Harris, J. A.: Soil microbial communities and restoration ecology: facilitators or followers, Science, 325, 573-574, 2009.

Hemsley, T.: Ecological response of atmospheric nitrogen deposition on reconstructed soils in the Athabasca Oil Sands region. M.Sc. Thesis. Department of Renewable Resources, University of Alberta, Edmonton, 128 pp., 2012.

Hobbie, S. E., Reich, P. B., Oleksyn, J., Ogdahl, M., Zytkowiak, R., Hale, C., and Karolewski, P.: Tree species effects on decomposition and forest floor dynamics in a common garden, Ecology, 87, 2288-2297, 2006.

Hobbs, R. J., Higgs, E., and Harris, J. A.: Novel ecosystems: implications for conservation and restoration, Trends Ecol. Evol., 24, 599-605, 2009.
Ibáñez, J. J. and Bockheim, J. G. (Eds.): Pedodiversity, Taylor and Francis, CRC Press, Boca Raton, FL, USA, 2013.

Insam, H. and Domnsch, K. H.: Relationship between soil organic carbon and microbial biomass on chronosequences of reclamation sites, Microb. Ecol., 15, 177-188, 1988.

Jenny, H.: Factors of Soil Formation, Dover Publications Inc., New York, 281 pp., 1941.

Jerabkova, L., Prescott, C. E., and Kishchuk, B. E.: Nitrogen availability in soil and forest floors of contrasting types of boreal mixedwood forests, Can. J. For. Res., 36, 112-122, 2006.

Kardol, P. and Wadle, D. A.: How understanding abovegroundbelowground linkages can assist restoration ecology, Trends Ecol. Evol., 25, 670-679, 2010.

Komada, H.: Clay minerals in Canadian soils: Their origin, distribution, and alteration, Can. J. Soil Sci., 59, 37-58, 1979.

Lamarche, J., Bradley, R., Paré, D., Légaré, S., and Bergeron, Y.: Soil parent material may control forest floor properties more than stand type or stand age in mixedwood boreal forests, Ecoscience, 11, 228-237, 2004.

Leckie, S. E., Prescott, C. E., and Grayston, S. J.: Forest floor microbial community response to tree species and fertilization of regenerating coniferous forests, Can. J. For. Res., 34, 1426-1435, 2004.

Leifeld, J. and Kögel-Knabner, I.: Soil organic matter fractions as early indicators for carbon stock changes under different landuse?, Geoderma, 124, 143-155, 2005.

Machulla, G., Bruns, M. A., and Scow, K. M.: Microbial properties of mine spoil materials in the initial stages of soil development, Soil Sci. Soc. Am. J., 69, 1069-1077, 2005.

McBratney, A. R.: On variation, uncertainty and informatics in environmental soil management, Aust. J. Soil Sci., 30, 913-935, 1992.

McCune, B. and Grace, J. B.: Analysis of Ecological Communities, MjM Software Design, Gleneden Beach, Oregon, USA, 2002.

McMillan, R., Quideau, S. A. MacKenzie, M. D., and Birjukova, O. V.: Nitrogen mineralization and microbial biomass in reclaimed boreal forest soils, J. Environ. Qual., 36, 1470-1478, 2007.

Merilä, P., Malmivaara-Lämsä, M., Spetz, P., Stark, S., Vierikko, K., Derome, J., and Fritze, H.: Soil organic matter quality as a link between microbial community structure and vegetation composition along a successional gradient in a boreal forest, Appl. Soil Ecol., 46, 259-267, 2010.

Mummey, D. L., Stahl, P. D., and Buyer, J. S.: Microbial biomarkers as an indicator of ecosystem recovery following surface mine reclamation, Appl. Soil Ecol., 21, 251-259, 2002.

Ohtonen, R. and Väre, H.: Vegetation composition determines microbial activities in a boreal forest soil, Microb. Ecol., 36, 328335, 1998.

Oil Sands Vegetation Reclamation Committee: Guidelines for reclamation to forest vegetation in the Alberta Oil Sands Region. \#ESD/LM/99-1, Alberta Environmental Protection - Environmental Service, Edmonton, 1998.

Ponge, J.-F., Jabiol, B., and Gégout, J.-C.: Geology and climate conditions affect more humus forms than forest canopies at large scale in temperature forests, Geoderma, 162, 187-195, 2011.

Prescott, C. E. and Grayston, S. J.: Tree species influence on microbial communities in litter and soil: current knowledge and research needs, For. Ecol. Manage., in press, 2013. 
Prescott, C. E. and Vesterdal, L.: Effects of British Columbia tree species on forest floor chemistry, in: Trees and Soil Interactions, Implications to Global Climate Change, edited by: Menyailo, O. and Binkley, D., NATO Science Series, Kluwer Academic, Dordrecht, the Netherlands, 2005.

Prescott, C. E., Maynard, D. G., and Laiho, R.: Humus in northern forests: friend or foe?, For. Ecol. Manage., 133, 23-36, 2000a.

Prescott, C. E., Zabek, L. M., Staley, C. L., and Kabzems, R.: Decomposition of broadleaf and needle litter in forests of British Columbia: influences of litter type, forest type and litter mixtures, Can. J. For. Res., 30, 1742-1750, 2000 b.

Prescott, C. E., Vesterdal, L., Pratt, J., Venner, K. H., de Montigny, L. M., and Trofymow, J. A.: Nutrient concentrations and nitrogen mineralization in forest floors of single species conifer plantations in coastal British Columbia, Can. J. For. Res., 30, 13411352, 2000c.

Prescott, C. E., Vesterdal, L., Simard, S. W., and Preston, C. M.: Influence of initial chemistry on decomposition of foliar litter in contrasting forest types in British Columbia, Can. J. For. Res., 34, 1714-1729, 2004.

Quideau, S. A., Chadwick, O. A., Graham, R. C., and Wood, H. B.: Base cation biogeochemistry and weathering under oak and pine: a controlled long-term experiment, Biogeochemistry, 35, 377-398, 1996.

Quideau, S. A., Chadwick, O. A., Benesi, A., Graham, R. C., and Anderson, M. A.: A direct link between forest vegetation type and soil organic matter composition, Geoderma, 104, 41-60, 2001.

Ratledge, C. and Wilkinson, S. G. (Eds.): Microbial Lipids, Volume 1, Academic Press, London, UK, 1988.

Rowland, S. M., Prescott, C. E., Grayston, S. J., Quideau, S. A., and Bradfield, G. E.: Recreating a functional forest soil in reclaimed oilsands in northern Alberta: an approach for measuring success in ecological restoration, J. Environ. Qual., 38, 1580-1590, 2009.
Ruiz-Jaen, M. C. and Aide, T. M.: Restoration success: how is it being measured?, Rest. Ecol., 13, 569-577, 2005.

Society for Ecological Restoration (SER) International Science and Policy Working Group: The SER international primer on ecological restoration, available at: http://www.ser.org (last access: September 2012), Society for Ecological Restoration International, Tucson, Arizona, 2004.

Soil Classification Working Group: The Canadian System of Soil Classification. Agriculture and Agri-Food Canada Publication 1646 (Revised), 1998.

Sorenson P. T., Quideau, S. A., MacKenzie, M. D., Landhäusser, S. M., and Oh, S. W.: Forest floor development and biochemical properties in reconstructed boreal forest soils, Appl. Soil Ecol., 49, 139-147, 2011.

Swallow, M., Quideau, S. A., MacKenzie, M. D., and Kishchuk, B. E.: Microbial community structure and function: the effect of silvicultural burning and topographic variability in northern Alberta, Soil Biol. Biochem., 41, 770-777, 2009.

Targulian, V. O. and Krasilnikov, P. V.: Soil system and pedogenic processes: self-organization, time scales, and environmental significance, Catena, 71, 373-381, 2007.

Turcotte, I., Quideau, S. A., and Oh, S.-W.: Organic matter quality in reclaimed boreal forest soils following oilsands mining, Org. Geochem., 40, 510-519, 2009.

Vetterlein, D. and Hüttl, R. F.: Can applied organic matter fulfil similar functions as soil organic matter? Risk-benefit analysis for organic matter application as a potential strategy for rehabilitation of disturbed ecosystems, Plant Soil, 213, 1-10, 1999.

Wall, D. H., Bardgett, R. D., and Kelly, E. F.: Biodiversity in the dark, Nat. Geosci., 3, 297-298, 2010.

Wardle, D. A., Bardgett R. D, Klironomos, J. N., Setälä, H., van der Putten, W. H., and Wall, D. H.: Ecological linkages between aboveground and belowground biota. Science, 304, 1629-1633, 2004. 